\title{
KEKUATAN MENGIKAT PUTUSAN AJUDIKASI BAWASLU DALAM SENGKETA PROSES PEMILU 2019
}

\author{
Ahmad Rizqi Robbani Kaban \\ (Mahasiswa Program S1 Fakultas Hukum Universitas Tarumanagara) \\ (E-mail: ahmadrrkaban@gmail.com)
}

\section{Rasji S.H, M.H}

(Corresponding Author)

(Dosen Fakultas Hukum Universitas Tarumanagara Meraih Sarjana Hukum pada Fakultas Hukum Universitas Indonesia, Magister Hukum pada Fakultas Hukum Universitas Indonesia)

(Email: rasji@gmail.com)

\begin{abstract}
The law governing general elections (elections) held every 5 years always changes. The latest is Law No.7 of 2017 (Elections Law) which accommodates 2019 Elections. In the Elections law law, the authority to resolve electoral disputes is regulated as one of the tasks of the Election Supervisory Body (Bawaslu). Bawaslu is given the authority to examine and decide on settlement of disputes through mediation if no agreement is reached then proceed to adjudication. Through this adjudication the problems occur, in the Election Law it is stated that the Bawaslu decision is final and binding. In fact, there is a decision on Bawaslu's adjudication which is not respected by the KPU. In the Election Law, the KPU is required to follow up on the decision no later than 3 (days) since the verdict was read. Instead of following up on the verdict, the KPU instead postponed following up on the verdict. Eventhough, the Election Law does not regulate the KPU's authority to delay, the KPU can only accept or reject it by making legal efforts to the Administrative Courts. So seeing the problem and being regulated by the Election Law, it is clear that the power of the Bawaslu adjudication decision is not final and binding. The Election Law must be corrected by giving firmness to the strength of the Bawaslu adjudication verdict whether it is final and binding or not.

Keywords: Adjudication, General Elections, Bawaslu.
\end{abstract}




\section{PENDAHULUAN}

\section{A. Latar Belakang}

Konstitusi merupakan hukum tertinggi di suatu negara (the supreme law of the land). Konstitusi berfungsi sebagai pegangan atau pedoman untuk menjalankan tata pemerintahan disuatu bangsa. Adapun bentuk konstitusi ada yang tertulis dan tidak terutlis. Konstitusi tertulis di Indonesia disebut dengan Undang-Undang Dasar Negara Kesatuan Republik Indonesia Tahun 1945 (UUD NKRI 1945). UUD NKRI 1945 telah memberikan dasar-dasar penyelenggaraan negara dan penataan kehidupan berbangsa yang demokratis. Hal ini tercermin dari adanya pengakuan kedaulatan rakyat yang dilaksanakan menurut UUD NKRI 1945 sebgaimana telah diatur dalam rumusan Pasal 1 ayat (2) UUD NKRI 1945, serta penegasan bahwa negara Indonesia berdasarkan atas hukum sesuai dengan Pasal 1 ayat (3) UUD NKRI 1945.

Prinsip dasar negara hukum yang demokratis tersebut diwujudkan dalam bentuk pengakuan dan jaminan terhadap hak asasi manusia (HAM) yang esensial dalam proses demokrasi, pengaturan mekanisme pemilihan wakil rakyat dan jabatan-jabatan publik sebagai perwujudan kedaulatan rakyat, serta penataan lembaga-lembaga negara berdasarkan prinsip check and balances. ${ }^{1}$ Pemilu telah diakui secara global sebagai sarana penyalur kedaulatan rakyat dalam bentuk partisipasi politik rakyat dalam menggunakan hak pilihnya. Teori demokrasi minimalis, sebagaimana dijelaskan oleh Joseph Shumpeter, menyebutkan bahwa pemilihan umum merupakan sebuah arena yang mewadahi kompetisi antara aktor-aktor politik yang meraih kekuasaan partisipasi politik rakyat untuk menentukan pilihan serta liberalisasi hak-hak sipil dan politik warga negara. ${ }^{2}$ Menurut A.S.S. Tambunan, Pemilu merupakan sarana atas pelaksanaan kedaulatan raykat yang pada hakekatnya

\footnotetext{
${ }^{1}$ Jimly Asshiddiqie, Menuju Negara Hukum yang Demokratis, (Jakarta: Kelompok Gramedia, 2009), hal. 377.

2 P. Antonius Sitepu, Studi Ilmu Politik, (Yogyakarta: Graha ilmu, 2012), hal. 4.
} 
merupakan pengakuan dan perwujudan dari pada hak-hak politik rakyat dan sekaligus merupakan pendelegasian hak-hak tersebut oleh rakyat kepada wakil-wakilnya untuk menjalankan pemerintahan. ${ }^{3}$ Pemilu secara konseptual merupakan sarana impelementasi kedaulatan rakyat.

Aktor utama dalam demokrasi yang menghubungkan kepentingan rakyat dengan negara dan pemerintah adalah partai politik, terutama dalam level demokrasi electoral dan demokrasi politik. Keduanya mencerminkan demokrasi perwakilan. ${ }^{4}$ Partai politik (parpol) sebagai organisasi khusus adalah peserta utama dalam meperebutkan kekuasaan politik terutama di lembaga eksekutif dan legislatif, melalui kompetisi sebuah wadah universal yang disebut pemilihan umum (Pemilu). Kemudian dirancanglah berbagai model sistem pemilu yang diadopsi oleh sebuah negara yang diterjemahkan melalui konstitusinya dan secara teknis diterjemahkan dalam produk UndangUndang bidang politik. ${ }^{5}$

Pengaturan sistem pemilu di Indonesia selalu mengalami perubahan dari waktu ke waktu dalam setiap penyelenggaraan pemilu. Dalam proses pembuatan pergantian regulasi setiap pemilu memiliki dinamika politik hukum, yakni latar belakang politik, ekonomi, sosial, budaya atas lahirnya produk undang-undang pemilu. Perubahan paket undang-undang politik dalam setiap pemilu yang berbeda ini membuktikan, bahwa telah terjadi perubahan sosial politik di Indonesia yang menuntut diakomodasi dalam pemilu untuk menuju politik hukum berupa kebijakan negara tentang hukum yang akan diberlakukan atau tidak diberlakukan dalam rangka mencapai tujuan negara. Sehingga, berdasarkan kepentingan politik serta kondisi sosial yang terus berubah dibuatlah aturan baru berkaitan dengan Pemilu 2019 yaitu

${ }^{3}$ Titik Triwulan Tutik, Konstruksi Hukum Tata Negara Indonesia Pasca Amandemen UUD 1945, (Jakarta: Kencana Prenada Media Group,2011), hal. 331.

${ }^{4}$ Agus Riwanto, Hukum Partai Politik dan Hukum Pemilu Di Indonesia, Cetakan ke-1, (Yogyakarta: Thafa Media, 2016), hal. 34.

${ }^{5}$ Ibid., hal. 49. 
Undang-Undang Nomor 7 tahun 2017 Tentang Pemilihan Umum (UU Pemilu) yang menggabungkan dan menggangitkan 3 Undang-Undang yang sebelumnya terpisah menjadi satu undang-undang tersendiri.

Pada penyelenggaraan pemilu 2019 terdapat beberapa tugas dan wewenang baru yang diamanatkan kepada Bawaslu, sebelumnya Bawaslu berfungsi dan bertugas hanya sebagai pengawas penyelenggaraan pemilu, sedangkan pada pemilu 2019 tugas dan wewenang Bawaslu bertambah. Tugas dan wewenang baru itu diatur di dalam Pasal 468 UU Pemilu, yang menyatakan bahwa Bawaslu berwenang untuk menyelesaikan sengketa administrasi pemilu dan sengketa proses pemilu. Wewenang menyelesaikan sengketa yang diamanatkan kepada Bawaslu adalah tugas baru bagi lembaga tersebut, karena pada pemilu-pemilu sebelumnya aturan tersebut belum diatur. Penyelesaian sengketa yang ditangani Bawaslu adalah penyelesaian sengketa administrasi Pemilu dan sengketa proses pemilu, dalam penyelesaian sengketa proses pemilu terdapat 2 (dua) tahapan, yaitu mediasi dan ajudikasi. Pada tahapan pertama yaitu mediasi, Bawaslu akan mempertemukan pihak yang bersengketa, apabila dalam mediasi tidak temui kesepakatan antara para pihak atas apa yang diperkarakan maka penyelesaian memasuki tahap sidang ajudikasi. $^{6}$

Penyelesaian sengketa melalui ajudikasi adalah suatu alur penyelesaian sengketa pemilu yang baru yang pada pemilu-pemilu sebelumnya belum digunakan. Sidang ajudikasi adalah produk hukum baru dalam alternatif penyelesaian sengketa pemilu. Dalam prakteknya, melalui sidang ajudikasi Bawaslu telah banyak mengeluarkan putusan-putusan yang bertentangan dan mengugurkan putusan yang dikeluarkan oleh KPU. Salah satunya adalah Partai Bulan Bintang (PBB) yang diloloskan oleh Bawaslu untuk bisa menjadi peserta pemilu 2019. Melalui sidang ajudikasi tersebut Bawaslu mengugurkan

\footnotetext{
${ }^{6}$ Ramlan Surbakti, Penegakan Hukum Pemilu dan Pilkada, (Jakarta: Kelompok Gramedia, 2016), hal. 6.
} 
keputusan KPU yang tidak meloloskan PBB, dan PBB menjadi satu-satunya peserta Pemilu yang ikut melalui sidang ajudikasi Bawaslu. Dalam UU Pemilu, diatur bahwa KPU harus menindaklanjuti putusan Bawaslu paling lama 3 (tiga) hari setelah putusan dibacakan. Namun, dalam beberapa kasus terdapat putusan ajudikasi yang di keluarkan Bawaslu berkaitan dengan penyelesaian sengketa proses pemilu yang tidak ditindaklanjuti oleh KPU. Seperti sengketa yang terjadi pada Calon Anggota Legislatif (Caleg) DPRD Provinsi DKI Jakarta dari partai Gerakan Indonesia Raya (Gerindra), Mohamad Taufik dengan KPUD DKI Jakarta. Taufik adalah mantan terpidana korupsi yang divonis 18 bulan penjara pada 27 april 2004 karena terjerat kasus korupsi saat menjabat sebagai Ketua KPUD DKI Jakarta. ${ }^{7}$

Bedasarkan dengan Peraturan Komisi Pemilihan Umum (PKPU) nomor 20 tahun 2018 yang melarang koruptor untuk menjadi Caleg. Dengan dasar PKPU tersebut, KPUD DKI Jakarta memutuskan untuk tidak meloloskan M. Taufik kedalam Daftar Calon Tetap (DCT) Caleg DPRD Provinsi DKI Jakarta yang disebabkan M. Taufik tidak memenuhi syarat administrasi karena pernah menjadi narapidana atas kasus korupsi. Akibat dari keputusan KPUD DKI Jakarta yang tidak meleloskan M. Taufik kedalam DCT dan menjadi Caleg DPRD Provinsi DKI Jakarta, M. Taufik mengajukan permohonan ke Bawaslu untuk menyelesaikan sengketa proses pemilu yang diakibatkan dari di keluarkannya keputusan KPU mengenai penetapan DCT Caleg DPRD Provinsi DKI Jakarta.

Berdasarkan 468 UU Pemilu, Bawaslu mempertemukan KPU dengan M. Taufik melalui sebuah mediasi untuk memusyawarahkan sengketa yang terjadi. Namun dalam mediasi tersebut, KPU dan M. Taufik tidak menemukan kesepakatan sehingga proses penyelesaiannya harus memasuki tahapan ajudikasi. Melalui ajudikasi, Bawaslu memutuskan untuk menggugurkan

\footnotetext{
${ }^{7}$ Indra Komara, "Pernah Jadi Napi Korupsi, M. Taufik Resmi Daftar Caleg", news.detik.com, 4 September 2018, diakses pada tanggal 18 Oktober 2018 Pukul 21.49 WIB
} 
keputusan KPU yang menyatakan M. Taufik tidak memenuhi syarat administrasi dan tidak dapat diloloskan untuk bisa masuk kedalam DCT Caleg DPRD Provinsi DKI Jakarta. Dengan digugurkannya keputusan KPU, Bawaslu memerintahkan KPU untuk meloloskan M. Taufik dan menyatakan yang bersangkutan memenuhi syarat sehingga dapat di masukan kedalam DCT Caleg DPRD Provinsi DKI Jakarta. ${ }^{8}$ Namun bukannya segera KPU melakukan tindakan untuk menerima atau menolak putusan ajudikasi Bawaslu dengan melakukan gugatan ke Pengadilan Tata Usaha Negara (PTUN), KPU malah menunda menindaklanjuti putusan ajudikasi Bawaslu.

KPU beralasan untuk menunda menanggapi putusan Bawaslu karena menunggu hasil judicial review teradap PKPU Nomor 20 tahun 2018. Penundaan untuk menindaklanjuti putusan ajudikasi Bawaslu yang dilakukan KPU telah bertentangan dengan beberapa aturan di dalam UU Pemilu. Berdasarkan Pasal 14, Pasal 17, dan Pasal 20 UU Pemilu telah jelas diatur bahwa KPU wajib melaksanakan putusan Bawaslu. Selanjutnya, Pasal 20 huruf j UU Pemilu juga mewajibkan KPU untuk segera melaksanakan putusan Bawaslu. Tindakan KPU yang melakukan penundaan untuk menindaklanjuti putusan Bawaslu juga bertentangan dengan Pasal 462 UU Pemilu yang menyatakan bahwa KPU wajib menindaklanjuti putusan Bawaslu paling lama 3 (tiga) hari sejak putusan dibacakan.

Dalam Pasal 469 UU Pemilu diatur bahwa putusan sidang ajudikasi bawaslu merupakan putusan yang bersifat final dan mengikat kecuali terhadap sengketa proses pemilu yang berkaitan dengan;

1. verifikasi Partai Politik peserta pemilu

2. penetapan daftar calon tetap anggota DPR, DPD, DPRD Provinsi, dan DPRD Kabupaten/Kota

3. penetapan Pasangan Calon.

8 Untung Widyanto, "Bawaslu Loloskan Taufik Gerindra, KPU DKI Tunggu Putusan MA", www.metro.tempo.co, 4 September 2018, diakses pada tanggal 18 Oktober 2018 Pukul 21.50 WIB 
Dalam hal penyelesaian sengketa proses pemilu sebagaimana pada ayat (1) yang dilakukan oleh Bawaslu tidak diterima oleh para pihak, para pihak dapat mengajukan upaya hukum ke pengadilan tata usaha negara. Pada pasal 469 tersebut telah jelas diatur bahwa putusan Bawaslu adalah mengikat dan final apabila para pihak tidak menerima maka satu-satunya jalaan yang diatur dalam UU Pemilu adalah melakukan gugatan ke PTUN.

Dengan melakukan penundaan dan tidak segera menindaklanjuti dan bahkan tidak melakukan gugatan ke PTUN setelah batasan 3 (tiga) hari yang ditentukan oleh UU Pemilu, sangat jelas bahwa KPU telah melakukan tindakan yang di luar batas dan melanggar peraturan yang ada. Di samping itu, kekuatan mengikat putusan ajudikasi Bawaslu yang diatur di dalam UU Pemilu pun patut dipertanyakan, apakah benar putusan ajudikasi Bawaslu itu final dan mengikat atau apakah tidak dan apabila terdapat kekuatan mengikat apa konsekuensi dari tindakan KPU yang tidak menindaklanjuti putusan tersebut melebhi batas waktu yang ditentukan di dalam UU Pemilu. Tindakan penundaan yang dilakukan KPU dan keberanian KPU untuk tidak menindaklanjuti putusan Bawaslu, menunjukan kelemahan putusan Bawaslu untuk bisa mengikat para pihak agar patuh terhadap putusan tersebut. Frase putusan Bawaslu adalah final dan mengikat menjadi tidak berarti.

Berdasarkan uraian di atas, menarik perhatian penulis untuk melakukan kajian dan penelitian lebih dalam mengenai kekuatan mengikat putusan Bawaslu dan menuangkannya kedalam proposal jurnal yang berjudul: "Kekuatan Mengikat Putusan Ajudikasi Badan Pengawas Pemilu Dalam Sengketa Proses Pemilu 2019”

\section{B. Perumusan Masalah}

Sebuah penelitian hukum pasti bertujuan untuk menjawab isu hukum yang ada. Oleh karena itu permasalahan yang akan dijawab oleh penelitian ini 
adalah Bagaimana kekuatan mengikat putusan ajudikasi badan pengawas pemilu dalam sengketa proses pemilu 2019?

\section{Metode Penelitian}

Penelitian hukum merupakan suatu kegiatan ilmiah yang didasarkan pada metode, sistematika, dan pemikiran tertentu yang bertujuan untuk mempelajari satu atau beberapa gejala hukum tertenu, dengan jalan menganalisanya. ${ }^{9}$ Metodologi pada hakekatnya memberikan pedoman, tentang cara-cara seorang ilmuwan mempelajari, menganalisa, dan memahami lingkungan-lingkungan yang dihadapinya. ${ }^{10}$ Sehingga metode penelitian hukum merupakan suatu kegiatan ilmiah yang didasarkan pada metode, sistematika, yang juga didasarkan pada analisa dan konstruksi, yang dilakukan secara metodologis dan konsisten.

\section{Jenis Penelitian}

Jenis penelitian yang digunakan di dalam penelitian ini adalah metode penelitian, normatif. Penelitian hukum normatif adalah mengkaji hukum yang dikonsepkan sebagai norma atau kaidah yang berlaku dalam masyarakat, dan menjadi acuan perilaku setiap orang. Biasanya penelitian hukum normatif yang diteliti hanya bahan pustaka atau data sekunder, yang mencakup bahan hukum primer, sekunder dan tersier. ${ }^{11}$

\section{Jenis dan Teknik Pengumpulan Data}

Data adalah hasil penelitian, baik yang berupa faktor-faktor atau angkaangka yang dapat dijadikan bahan untuk suatu informasi. Dalam penelitian ini, jenis data yang di gunakan adalah jenis data sekunder. Jenis data sekunder adalah data yang diperoleh dari hasil penelahaan kepustakaan atau penelahaan

\footnotetext{
${ }^{9}$ Soerjono Soekanto, Op.Cit., hal. 43.

${ }^{10}$ Ibid., hal. 6.

${ }^{11}$ Ibid., hal. 52.
} 
terhadap berbagai literatur atau bahan pustaka yang berkaitan dengan masalah atau materi penelitian yang sering disebut bahan hukum. ${ }^{12}$ Ditinjau dari kekuatan mengikatnya data sekunder digolongkan ke dalam:

a. Bahan hukum primer

Bahan hukum primer merupakan bahan hukum yang bersifat autoritatif, artinya mempunyai otoritas. Bahan hukum primer terdiri dari perundangundangan, catatan-catatan atau risalah dalam pembuatan perundang-undangan, catatan resmi dan putusan-putusan hakim. ${ }^{13}$ Bahan hukum primer yang digunakan dalam penulisan ini, yaitu:

1) Undang-Undang Dasar Negara Republik Indonesia Tahun 1945.

2) Undang-Undang Nomor 7 Tahun 2017 tentang Pemilihan Umum.

3) Peraturan Bawaslu Republik Indonesa Nomor 18 Tahun 2018 tentang Perubahan Atas Peraturan Badan Pengawas Pemilu Nomor 18 Tahun 2017 tentang Tata Cara Penyelesaian Sengketa Proses Pemilihan Umum.

4) Peratura Komisi Pemilihan Umum Republik Indonesia Nomor 20 Tahun 2018 Tentang Pencalonan Anggota Dewan Perwakilan Rakyat, Dewan Perwakilan Rakyat Daerah Provinsi, Dewan Perwakilan Rakyat Daerah Kabupaten/Kota.

5) Peraturan Dewan Kehormatan Penyelenggara Pemilihan Umum Republik Indonesia Nomor 2 Tahun 2017 Tentang Kode Etik dan Pedoman Perilaku Penyelenggara Pemilihan Umum.

6) Putusan Badan Pengawas Pemilihan Umum Republik Indonesia, Penyelesaian Sengketa Proses Pemilihan Umum Nomor Register: 004/REG.LG/DPRD/12.00/VIII/2018.

b. Bahan Hukum Sekunder

\footnotetext{
12 Ibid., hal 184.

13 Peter Mahmud Marzuki, Penelitian Hukum Edisi Revisi, (Jakarta: Kencana Prenada Media Group, 2013), hal. 181.
} 
Bahan hukum sekunder berupa semua publikasi tentang hukum yang bukan merupakan dokumen-dokumen resmi.14 Publikasi yang dimaksud adalah publikasi mengenai hukum meliputi teks, kamus-kamus hukum, jurnaljurnal hukum, dan komentar-komentar atas putusan pengadilan. ${ }^{15}$ Bahan hukum sekunder yang digunakan dalam penulisan ini adalah berbagai kepustakaan hukum yakni buku atau jurnal hukum yang berisi mengenai prinsip-prinsip dasar (asas hukum), pandangan para ahli hukum (doktrin) berupa semua publikasi tentang hukum.

c. Bahan Non - Hukum

Bahan non-hukum adalahh bahan penunjang di luar bahan hukum primer dan sekunder sebagai bahan pelengkap bukan yang utama serta memberi petunjuk tambahan terhadap bahan hukum yang penulis gunakan. ${ }^{16}$ Seperti Kamus Besar Bahasa Indonesia (KBBI).

\section{Pendekatan Penelitian}

Di dalam penelitian hukum terdapat beberapa pendekatan. Dengan pendekatan tersebut, peneliti akan mendapatkan informasi dari berbagai aspek mengenai isu yang sedang dicoba untuk dicari jawabannya. ${ }^{17}$ Dalam penelitian hukum dikenal ada 5 (lima) macam pendekatan penelitian hukum, yaitu pendekatan peraturan perundang-undangan (statue approach), pendekatan historis (historical approach), pendekatan komparatif (comparative approach), pendekatan kasus (case approach), dan pendekatan konseptual (conceptual approach). ${ }^{18}$

\footnotetext{
14 Ibid., hal. 181.

${ }^{15}$ H. Zainuddin Ali, Metode Penelitian Hukum, (Jakarta: Sinar Grafika, 2009), hal 47.

16 Mukti Fajar ND dan Yulianto Achmad, Dualisme Penelitian Hukum Normatif dan Empiris, (Yogyakarta: Pustaka Belajar, 2015), hal. 133.

${ }^{17}$ Peter Mahmud Marzuki. Op.Cit., hal. 133.

${ }^{18}$ Zaenal Arifin, Metode Penulisan Ilmiah, (Jakarta: Pustaka Mandiri, 2002), hal. 47.
} 
Pada penelitian ini akan digunakan pendekatan undang-undang (statue approach) dalam metode hukum normatif. Pendekatan undang-undang (statue approach) adalah pendekatan yang dilakukan dengan menelaah semua undang-undang dan regulasi yang berhubungan dengan isu hukum yang sedang diteliti, yaitu undang-undang dan peraturan yang berkaitan dengan penyelesaian sengketa verifikasi pemilu melalui sidang ajudikasi Bawaslu.

\section{Sifat Penelitian}

Dalam Penelitian ini spesifikasi penelitian yang digunakan adalah spesifikasi yang bersifat Preskriptif. Dalam penelitian perspektif ini akan memberikan argumentasi atas hasil yang diperoleh melalui sumber-sumber penelitian. Adapun sumber-sumber penelitian merupakan hasil perkembangan pikiran berdasarkan pendekataan normatif terhadap hukum positif yang berlaku terhadap kasus yang diangkat diteliti. Argumentasi tersebut berupa penilaian mengenai benar atau salahnya, atau apa yang seyogyanya menurut hukum terhadap fakta atau peristiwa hukum dari hasil penelitian. ${ }^{19}$

\section{Teknik Analisis Data}

Teknik analisis data merupakan kegiatan dalam penelitian yang berupa melakukan kajian atau telaah terhadap hasil pengolahan data yang dibantu dengan teori-teori yang telah di dapatkan sebelumnya. Secara sederhana analisis data ini disebut sebagai kegiatan memberikan telaah, yang dapat berarti menentang, mengkritik, mendukung, menambah atau memberi komentar dan kemudian membuat suatu kesimpulan terhadap hasil penelitian dengan pikiran sendiri dan bantuan teori yang telah dikuasainya. Teknik analisis yang akan dilakukan di dalam penelitian ini adalah teknik analisis data secara kualitatif, yaitu Penelitian kualitatif menekankan pada kedalaman

${ }^{19}$ Amiruddin dan H. Zainal Asikin, Pengantar Metode Penelitian Hukum, (Jakarta: Persada, 2006), hal. 24. 
data yang didapatkan oleh peneliti. Selain itu, proses dan makna (perspektif subjek) lebih ditonjolkan dalam penelitian kualitatif. Landasan teori dimanfaatkan sebagai pemandu agar fokus penelitian sesuai dengan fakta di lapangan. Selain itu landasan teori juga bermanfaat untuk memberikan gambaran umum tentang latar penelitian dan sebagai bahan pembahasan hasil penelitian.

\section{Pembahasan}

Penulis melakukan penelitian ini dengan mengangkat permasalahan mengenai bagaimana kekuatan hukum mengikat putusan ajudikasi badan pengawas pemilu dalam sengketa proses pemilu 2019, dengan studi kasus terhadap tindakan KPUD DKI Jakarta yang melakukan penundaan terhadap putusan ajudikasi Bawaslu terkait dengan penyelesaian sengketa M. Taufik yang tidak diloloskan menjadi Caleg DPRD Provinsi DKI Jakarta akibat dari di keluarkannya Peraturan Komisi Pemilihan Umum (PKPU) No.20 tahun 2018.

Negara Republik Indonesia merupakan negara yang berdasarkan pada demokrasi, UUD NKRI 1945 telah mengatur bahwa kedaulatan berada di tangan rakyat dan dilaksanakan menuru UUD NKRI 1945. Pasal 1 ayat (2) UUD NKRI 1945 adalah dasar hukum untuk dijalankannya sistem demokrasi di Indonesia yang dimana kekuasaan tertinggi berada di tangan rakyat. Prinsip dasar kehidupan negara yang demokrasi adalah dengan diberikannya hak untuk setiap warga negara untuk aktif di dalam proses politik. Untuk bisa merealisasikan amanat UUD NKRI 1945 tentang menjalankan kekuasaan tertinggi ditangan rakyat dan dalam bingkai demokrasi adalah dengan terselenggaranya Pemilihan umum secara regular dengan prinsip yang langsung, umum, bebas, jujur, rahasia, dan adil. Pemilu merupakan mandat dari konstitusi yang wajib dilaksanakan oleh pemerintah, dalam hal memastikan dan melindungi pelaksanaan kedaulatan rakyat dalam 
menyalurkan hak-hak poltiiknya. Salah satu prinsip dasar dari suatu negara hukum yang demokratis adalah adanya jaminan yang berkeadilan bagi rakyat dalam menentukan pilihan terhadap pemimpin negara dan wakil yang akan memperjuangkan kepentingannya. ${ }^{20}$

Di dalam UUD NKRI 1945 tidak diatur secara jelas mengenai aturan tentang pelaksanaan pemilu. Pasal 1 ayat (2) UUD NKRI 1945 memuat aturan abstrak tentang memberikan kekuasaan tertinggi kepada rakyat. Amanat Pasal 1 ayat (2) itu lalu dikonkritkan dengan penyelenggaraan pemilihan umum yang diadakan setiap 5 tahun sekali. Sepanjang sejarah berdirinya negara Indonesia, Pemilu di Indonesia telah dilaksanakan 11 kali, yang dimulai sejak 1955, 1971, 1977, 1982, 1987, 1992, 1997, 1999, 2004, 2009, dan $2014 .^{21}$ Setiap pelaksanaan pemilihan umum yang telah dilaksanakan memiliki dasar hukum yang berbeda. Perbedaan dasar hukum itu diakibatkan karena berkembangnya ilmu pengetahuan dan perubahaan kondisi sosial dan politik di tengah-tengah masyarakat. Sebelum reformasi pada tahun 1999, penyelenggaraan pemilu dinilai penuh dengan intrik-intrik permaian yang dipercaya dilakukan oleh penguasa, dan pemilu-pemilu yang diselenggarakan dinilai jauh dari nilai-nilai demokrasi, di setiap pemilihan selalu dimenangi oleh partai yang sama dan perolehan suara yang diraih para peserta pemilu selalu memberikan jarak yang signifikan. ${ }^{22}$

Pasca reformasi, aturan tentang penyelenggaraan pemilu terus berubah mengikuti kondisi sosial dan politik yang dinamis. Pemilu yang diselenggarakan pada tahun 1999, 2004, 2009, 2014 memiliki dasar hukum yang berbeda-beda. Pada pemilu 2014 terdapat 4 Undang-Undang yang berkaitan dengan pemilu, seperti Undang-Undang Nomor 42 tahun 2008 tentang pemilu Presiden dan Wakil Presiden, Undang-Undang Nomor 2 tahun

${ }^{20}$ Fajlurrahman Jurdi, Pengantar Hukum Pemilihan Umum, (Jakarta: Kencana, 2018), hal. 42.

${ }^{21}$ lbid, hal. 153.

${ }^{22}$ Ibid 
2011 tentang Partai Politik, Undang-Undang Nomor 15 tahun 2011 tentang Penyelenggara Pemilu, dan Undang-Undang Nomor 8 tahun 2012 tentan Pemilu anggota DPR, DPD, dan DPRD.

Dalam pelaksanaan pemilu pasca reformasi yang telah berlangsung sejak 1999 hingga 2014, selalu terdapat permasalahan-permasalahan pemilu yang berkaitan dengan sengketa administrasi, sengketa proses pemilu, dan sengketa atas hasil pemilu. Sengketa-sengketa yang terjadi di setiap Pemilu tidak dapat dihindarkan, maka untuk menjamin suatu pemilu yang berjalan dengan prinsip-prinsipnya maka dirasa perlu untuk adanya pengaturan tentang lembaga yang berwenang untuk menyelesaikan sengketa-sengketa yang terjadi di dalam pemilu. Pada pemilu 2014, wewenang penyelesaian sengketa berada pada wewenang Peradilan Tata Usaha Negara (PTUN) dan Mahakamah Konstitusi. PTUN diberikan kewenangan untuk menyelesaikan sengketa yang berkaitan dengan sengketa administrasi dan proses pemilu sedangkan Mahkamah Konstitusi berwenang untuk menyelsaikan sengeketa yang berkaitan dengan hasill Pemilu. Dalam Pemilu 2019 dan berdasarkan Pasal 95 huruf d UU Pemilu, mengatur wewenang Badan Pengawas Pemilu (Bawaslu) selaku penyelenggara pemilu yang bertugas untuk mengawasi jalannya Pemilu juga menjadi salah satu lembaga yang berwenang menerima laporan, memeriksa, melakukan mediasi dan ajudikasi serta memutus penyelesaian sengketa pemilu. Maka apabila dikatikan dengan teori kewenangan, wewenang Bawaslu yang dapat melakukan penindakan penyelesaian sengketa pemilu didapat melalui atribusi yang karena wewenang itu diberikan melalui undang-undang.

Sengketa-sengketa yang menjadi wewenang Bawaslu untuk diselesaikannya adalah sengketa administratif pemilu dan sengketa proses pemilu. Sengketa administratif pemilu adalah sengketa pemilu yang berkaitan dengan tata cara, prosedur, atau mekanisme yang berkaitan dengan administrasi pelaksanaan pemilu (yang tidak berkaitan dengan tindak pidana). 
Sedangkan sengketa proses pemilu adalah sengketa yang terjadi antara para peserta pemilu dan sengketa yang terjadi antara peserta dengan penyelenggara pemilu, sengketa proses pemilu dapat terjadi akibat dikeluarkannya keputusan KPU yang diarasa tidak sesuai dengan peraturan yang ada dan merugikan salah satu pihak. Dalam penyelesaian sengketa proses pemilu, calon peserta / peserta pemilu melapor kepada Bawaslu dengan memasukan permohonan yang memuat nama dan alamat pemohon, pihak termohon (peserta pemilu / penyelenggara pemilu), dan keputusan KPU yang menjadi sebebab sengketa. Bawaslu memberiksa dan memutus sengketa proses pemilu paling lama 12 hari sejak diterima permohonannya. Bawaslu dalam melakukan penyelesaian sengketa proses pemilu melelaui tahapan;

1. Menerima dan mengkaji permohonanan penyelesaian sengketa proses pemilu, dan

2. Memepertemukan para pihak yang bersengketa dan dilakukan mediasi atau musyawarah mufakat untuk mencapai kesepakatan

Apabila dalam mediasi tidak ditemukan kesepakatan maka Bawaslu memproses penyelesaian sengketa pemilu melalui sidang ajudikasi. Pasal 469 UU Pemilu menjelaskan bahwa putusan ajudikasi Bawaslu mengenai penylesaian sengketa proses pemilu merupakan putusan yang bersifat final dan mengikat, kecuali putusan terhadap sengekta proses pemilu yang berkaitan dengan:

1. Verifikasi partai politik peserta pemilu

2. Penetapan daftar calon tetap anggota, DPR, DPD, DPRD Provinsi, dan DPRD Kabupaten/Kota; dan,

3. Penetapan pasangan calon

Selanjutnya, apabila putusan yang dikeluarkan Bawaslu tidak diterima oleh para pihak maka para pihak dapat mengajukan upaya hukum ke PTUN. Keputusan yang dikeluarkan oleh Bawaslu wajib ditindaklanjuti oleh KPU paling lama 3 (tiga) hari kerja sejak tanggal putusan dibacakan. KPU wajib 
menindak lanjuti putusan Bawaslu dengan meneribitkan keputusan KPU yang isinya menerima atau menolak dan melakukan upaya hukum ke PTUN. apabila KPU atau peserta pemilu tidak menindaklanjuti putusan Bawaslu, maka Bawaslu dapat mengadukan pihak yang terkait ke Dewan Kehormatan Penyelenggara Pemilu (DKPP).

Dalam prakteknya, kekuatan hukum mengikat putusan ajudikasi Bawaslu dalam penyelesaian sengketa proses pemilu menjadi sebuah tanda tanya besar. Seperti yang terjadi pada kasus yang penulis angkat di dalam penelitian ini. Pasca diberlakukannya Peraturan Komisi Pemilihan Umum (PKPU) Nomor 20 tahun 2018 yang memuat larangan bagi mantan tepidana koruptor untuk mencalonkan diri di dalam pemilu 2019 menimbulkan permasalahan. Akibat dari diberlakukan PKPU oleh KPU membuat 38 bakal calon anggota legislatif (bacaleg) yang sebelumnya telah dinyatakan memenuhi syarat (MS) dan berhak mengikuti serta menjadi calon anggota legislatif yang akan dipilih di dalam pemilu 2019 menjadi tidak memenuhi syarat (TMS) dan tercoret dari daftar nama calon sementara (DCS) dan mengakibatkan yang bersangkutan tidak bisa mengikuti pemilu 2019 sebagai calon anggota legislatif.

Salah satu dari 38 nama yang dinyatakan TMS dan gagal menjadi caleg pada pemilu 2019 adalah Mohammad Taufik, yang juga mencalonkan diri sebagai caleg DPRD Provinsi DKI Jakarta. Pada tahun 2004, M. Taufik pernah dihukum pidana penjara selama 18 bulan akibat dari tindak pidana Korupsi yang dilakukannya saat menjabat sebagai ketua KPUD DKI Jakarta periode 2003-2008. Akibat dari kasus yang pernah dialami M. Taufik tersebut menyebabkan dirinya dinyatakan TMS dan tercoret dari DCS caleg DPRD Provinsi DKI Jakarta. Sebelum PKPU No.20 tahun 2018 diberlakukan, larangan bagi mantan narapidana koruptor tidak menjadi penghalang seseorang untuk bisa menjadi caleg pada pemilu 2019. Akibat diberlakukannya PKPU No.20 tahun 2018 membuat sengketa di beberapa daerah, dan salah satunya di Jakarta. M. Taufik merasa dirugikan akibat 
adanya PKPU No.20 tahun 2018 tersebut, sehingga M. Taufik melayangkan gugatan ke Bawaslu akibat keputusan KPU yang menyatakan dirinya TMS dan tidak bisa menjadi caleg DPRD Provinsi DKI Jakarta pada pemilu 2019.

M. Taufik mengajukan permohonan penyelesaian sengketa proses pemilu ke Bawaslu DKI Jakarta dengan objek permohonan surat keputusan KPU yang menyatakan dirinya TMS dan tercoret dari DCS. Sesuai dengan Pasal 468 ayat (3) UU Pemilu, Bawaslu menerima dan mengkaji permohonan M. Taufik dan selanjutnya mempertemukannya dengan KPUD DKI Jakarta untuk mencapai kesepakatan dalam tahap mediasi. Dalam tahap mediasi yang dilakukan Bawaslu dengan mempertemukan M. Taufik dan KPUD DKI Jakarta tidak menemukan titik temu hingga tidak ada kesepakatan yang dapat diputus Bawaslu. Sesuai dengan Pasal 468 ayat (4) maka penyelesaian sengketa tersebut harus diputus melalui sidang ajudikasi. Melalui sidang ajudikasi, Bawaslu memutuskan untuk menerima permohonan M. Taufik dan menyatakan yang bersangkutan telah memenuhi syarat sehingga dapat dimasukan ke dalam DCT dan berhak untuk menjadi Caleg DPRD Provinsi DKI Jakarta dalam pemilu 2019. Bawaslu berpandangan bawhwa aturan pelarangan mantan napi koruptor yang diatur di dalam PKPU tersebut bukan wewenang KPU, maka apabila dikaitkan dengan teori keputusan, PKPU itu adalah Onbevoegdheid ratione materiae atau keputusan yang batal demi hukum. Dalam amar putusan nya, Bawaslu memerintahkan KPUD DKI Jakarta untuk melaksanakan putusan tersebut.

Melihat ketentuan pada Pasal 469 UU Pemilu, putusan Bawaslu yang berkaitan dengan penetapan DCT anggota DPR, DPD, DPRD Provinsi, dan DPRD Kabupaten/Kota apabila putusan Bawaslu tidak diterima para pihak, para pihak dapat mengajukan upaya hukum ke PTUN. Selanjutnya, Pasal 462 UU Pemilu dengan tegas mengatur bahwa KPU/KPUD wajib menindaklanjuti putusan Bawaslu paling lama 3 (tiga) hari sejak tanggal putusan dibacakan. Maka berdasarkan ketentuan yang tertuang dalam UU Pemilu tindakan yang 
dapat dilakukan KPUD DKI Jakarta hanya menerima putusan Bawaslu dengan melaksanakan putusannya atau menolak dan mengajukan upaya hukum ke PTUN. Namun, bukanya menerima atau menolak putusan Bawaslu, KPU RI memerintahkan kepada KPUD DKI untuk menunda menindaklanjuti putusan Bawaslu melalui surat edaran KPU RI Nomor 991 tahun 2018, sampai ada putusan Mahkamah Agung terkait uji materi tentang PKPU Nomor 20 tahun 2018.

Kewajiban KPU untuk menindaklanjuti putusan Bawaslu adalah dengan mengeluarkan keputusan KPU baru, yang isinya menerima atau menolak dan apabila menolak maka harus melaukan upaya hukum ke PTUN. Tindakan KPU RI yang memerintahkan KPUD DKI Jakarta untuk menunda menindaklanjuti putusan Bawaslu telah melanggar norma-norma yang tercantum di UU Pemilu. Di dalam UU Pemilu tidak aturan yang memberikan kewenangan kepada KPU untuk melakukan penundaan. Tindakan yang bisa dilakukan oleh KPU dalam menindaklanjuti putusan Bawaslu hanyalah mengeluarkan keputusan KPU yang menerima putusan Bawaslu atau menolak putusan Bawaslu dan melakukan upaya hukum ke PTUN. Tindakan KPU yang berani menunda menindaklanjuti putusan Bawaslu telah melanggar aturan di dalam UU Pemilu. Berdasarkan Pasal 464 UU Pemilu, apabila KPU tidak menindaklanjuti putusan Bawaslu maka Bawaslu dapat mengadukan ke DKPP untuk dilakukan pemeriksaan. Di samping itu, tindakan KPU juga telah melanggar ketentuan pada Pasal 518 UU Pemilu yang dengan tegas mengatur bahwa setiap anggota KPU yang tidak menindaklanjuti temuan Bawaslu yang berkaitan dengan pelaksanaan verifikasi kelengkapan administrasi bakal calon anggota DPR, DPD, DPRD Provinsi, dan DPRD Kabupaten/Kota dipidana penjara paling lama 3 (tiga) tahun dan denda paling banyak Rp.36.000.000 (tiga puluh enam juta rupiah).

Melalui surat edaran KPU RI nomor 991 tahun 2018 KPU RI memerintahkan seluruh KPU Daerah yang bersengketa di Bawaslu untuk 
menunda menindaklanjuti putusan Bawaslu. Melalui surat edaran tersebut maka tindakan penundaan pelaksanaan putusan Bawaslu bukanlah tindakan perseorangan. Dengan di keluarkannya surat edaran tersebut terlihat jelas bahwa kekuatan hukum putusan Bawaslu sejatinya belum dapat mengikat para pihak karena sanksi yang berkaitan dengan tidak menindaklanjuti putusan Bawaslu masih kurang tegas.

Pada Pasal 464 UU Pemilu menjelaskan bahwa KPU dapat dilaporkan oleh Bawaslu ke DKPP apabila tidak menindaklanjuti putusan Bawaslu. Pada pasal tersebut hanya mengatur Bawaslu yang menjadi pelapor apabila putusannya tidak ditindaklanjuti padahal dalam praktiknya yang akan dirugikan atas tidak ditindaklanjutinya putusan Bawaslu adalah para pihak yang bersengketa bukan Bawaslu, maka wewenang untuk melaporkan lebih tepat kepada para pihak yang dirugikan. Di samping itu, pelaporan yang diadukan ke DKPP hanya berkaitan dengan kode etik. DKPP tidak bisa memerintahkan KPU untuk menindaklanjuti atau memberikan pengaruh terhadap substansi permsalahan. DKPP hanya memeriksa dan memutuskan sanksi yang berkaitan dengan kode etik penyelenggara pemilu. Sanksi yang dapat di berikan DKPP pun masih terlihat kurang tegas, di dalam Peraturan DKPP RI Nomor 2 tahun 2017 tentang kode etik dan pedoman perliaku penyelenggara pemilihan umum, pemberian sanksi yang dijatuhkan DKPP harus melalui tahapan yang berbelit belit. Pemberian sanksi harus melalui rapat pleno dengan para anggota DKPP secara musyawarah. Apabila dalam musyawarah tidak dapat tidik temu maka sanski tidak dapat dijatuhi.

Selanjutnya, dalam Pasal 518 UU Pemilu telah diatur tentang sanksi pidana kepada anggota KPU yang tidak menindaklanjuti putusan Bawaslu. Namun pada Pasal tersebut hanya mengatur tentang tindakan perseorangan. Di samping itu, untuk bisa memeriksa anggota KPU yang melanggar ketentuan Pasal 518 UU Pemilu, pihak kepolisian tidak bisa melakukan tindakan tanpa adanya pelaporan. Apabila terdapat anggota KPU yang tidak menindaklanjuti 
temuan Bawaslu, namun tidak ada pihak yang melaporkan anggota KPU tersebut karena tidak menindaklanjuti putusan Bawaslu maka anggota yang telah melakukan tindakan tersebut tidak dapat di proses dan di hukum dengan ketentuan yang tercantum di dalam Pasal 518.

Dari 2 (dua) Pasal yang telah dibahas di atas terlihat jelas bahwa tindakan KPU yang berani melanggar peraturan yang tercantum di UU Pemilu, adalah akibat dari ketidak tegasan aturan yang mengatur tentang kekuatan mengikat putusan ajudikasi Bawaslu. Sanksi-sanksi dari tidak menindaklanjuti putusan dan aturan yang tertuang di dalam UU Pemilu masih belum menegaskan kedudukan kekuatan putusan Bawaslu. Dengan tidak jelasnya kekuatan mengikat dan tidak tegasnya aturan tentang kekuatan putusan Bawaslu tersebut, memberikan celah kepada KPU untuk tidak menghormati putusan Bawaslu. Karena, dari tanggal ditetapkannya putusan Bawaslu sampai dilakukan penundaaan pelaksanakan putusan Bawaslu yang menunggu putusan MA berkitan dengan uji materil PKPU No.20 tahun 2018 mencapai 21 hari. Dalam kurun waktu 21 hari tersebut tidak ada tindakan dari pihak manapun untuk memberikan sanksi kepada KPU, padahal sangat jelas bahwa KPU telah melanggar ketentuan UU Pemilu yang mewajibkan untuk menindaklanjuti putusan Bawaslu dalam waktu 3 (tiga) hari.

Selain aturan yang tidak tegas mengatur tentang sanksi dari tidak ditindaklanjuti nya putusan Bawaslu, terdapat juga Pasal dalam UU Pemilu yang tidak memberikan kekuatan yang jelas kepada putusan Bawaslu. Pada ayat (1) Pasal 469 UU Pemilu terdapat frase yang menjelaskan bahwa putusan Bawaslu mengenai penyelesaian sengketa proses Pemilu merupakan yang bersifat final dan mengikat. Namun, pada frase berikutnya kekuatan final dan mengikat itu dimentahkan dengan kata "kecuali" putusan terhadap sengketa proses pemilu yang berkaitan dengan;

1. Verifikasi Partai Politik peserta Pemilu 
2. Penetapan daftar calon tetap anggota DPR, DPD, DPRD Provinsi, dan DPRD Kabupaten/Kota; dan,

3. Penetapan pasangan calon

Pada frase awal telah jelas memberikan kekuatan putusan Bawaslu adalah final dan mengikat namun difrase selanjutnya kekuatan itu seakan dihapuskan. Kata kecuali dalam pasal tersebut memberikan ketidak jelasan mengenai kekuatan mengikat putusan Bawaslu.

Dalam penyelesaian sengketa pemilu yang diatur di dalam UU Pemilu, terdapat 2 kategori sengketa yang dapat di selesaikan melalui Bawaslu, yaitu:

1. Sengketa Administratif Pemilu, diakibatkan karena adanya pelanggaran terhadap tata cara, prosedur, atau mekanisme yang berkaitan dengan administrasi pelaksanaan Pemilu. Dalam penyelesaian sengketa administratif Pemilu. Bawaslu menerima laporan dengan memeriksa dan mengkaji serta membuat rekomendasi atas hasil kajiannya mengenai pelanggaran administratif Pemilu. Dalam proses penyelesaian sengketa administratif Pemilu, tidak terdapat tahapan Mediasi dan ajudikasi. Dalam sengketa ini Bawaslu bekerja setelah adanya laporan/temuan dengan diberikan jangka waktu 14 hari lalu untuk memutuskan, dan memutus suatu putusan yang berupa:

a. Perbaikan adminsitrasi terhadap tata cara, prosedur, atau mekanisme sesuai dengan peraturan perundang-undangan

b. Teguran tertulis

c. Tidak dilakukan pada tahapan tertentu dalam Penyelenggaraan Pemilu; dan,

d. Sanksi administratif lainnya sesuai dengan ketentuan dalam UndangUndang No.7 tahun 2017

Sengketa Proses Pemilu, sengketa ini terjadi antara Peserta pemilu dengan peserta pemilu lainnya atau sengketa yang terjadi antara peserta Pemilu dengan Penyelenggara Pemilu (KPU), sengketa proses pemilu diakbatkan dari 
dikeluarkannya keputusan KPU yang dirasa merugikan pihak tertentu dan telah melanggar ketentuan yang tertuang di dalam UU Pemilu. Dalam penyelesaian sengketa proses pemilu ini Bawaslu diberikan wewenang untuk memerika, mengkaji, dan memutus sengketa proses pemilu melalui tahapan Mediasi, dan ajudikasi apabila tidak tercapainya kesepakatan dalam mediasi.

Dari 2 (dua) kategori sengketa yang dapat di selesaikan oleh Bawaslu di atas, dapat dilihat bahwa hanya sengketa proses pemilu sajalah yang memerlukan tahapan mediasi dan ajudikasi. Putusan yang dikeluarkan melalui tahapan ajudikasi Bawaslu adalah putusan sengketa yang berkaitan dengan proses pemilu, maka kalimat pada Pasal 469 yang menyatakan bahwa Putusan Bawaslu adalah final dan mengikat merupakan kalimat yang memberikan kedudukan atau kekuaatan kepada putusan ajudikasi Bawaslu bersifat final. Tetapi, kekuatan tersebut lansung di hapus pada frase selanjutnya yang memberikan pengecualian kepada perihal-perihal tertentu. Pada dasarnya, penyelesaian sengketa proses pemilu pastilah berkaitan dengan verifikasi partai politik peserta pemilu, penetapan DCT anggota DPR, DPD, DPRD Provinsi, dan DPRD Kabupaten/Kota atau penetapan pasangan calon, maka putusan ajudikasi Bawaslu tidak akan pernah final dan mengikat karena putusan ajudikasi yang dikeluarkan Bawaslu pasti berkaitan dengan hal-hal yang dikecualikan di dalam UU Pemilu.

\section{Penutup}

\section{A. Kesimpulan}

Berdasarkan kepada pembahasan pada bab sebelumnya, maka dapat disimpulkan sebagai berikut:

Kekuatan hukum mengikat putusan Bawaslu yang diatur di dalam Undang-Undang No.7 tahun 2017 tentang Pemilihan Umum (UU Pemilu) masih dirasa belum begitu tegas. Hal ini dapat dilihat dari tindakan KPU yang berani untuk menunda menindaklanjuti putusan Bawaslu lebih dari 3 (tiga) 
hari. Di samping itu, kekuatan final dan mengikat putusan Bawaslu terhadap sengketa proses pemilu masih tidak jelas pengaturannya, karena sengketa yang berada dalam proses pemilu pasti berkaitan dengan, verifikasi partai politik peserta pemilu, penetapan daftar calon tetap anggota DPR, DPD, DPRD Provinsi, dan DPRD Kabupaten/Kota, dan penetapan pasangan calon, sedangkan terhadap hal-hal tersebut diatas apabila para pihak tidak menerima dapat mengajukan upaya hukum ke PTUN. Maka sejatinya kekuatan putusan Bawaslu itu tidak akan pernah mengikat karena putusan Bawaslu pasti berkaitan dengan hal-hal tersebut. Hal-hal diatas juga diperparah dengan sanksi yang diatur didalam UU Pemilu, DKPP yang menjadi salah satu lembaga pengawas kinerja penyelenggara pemilu dapat bertindak apabila ada laporan dari Bawaslu padahal yang menjadi korban dari tidak dijalankannya putusan Bawaslu adalah Partai politik atau calon anggota legislatif dari Partai politik bukan Bawaslu. Selanjutnya, pidana yang diatur hanyalah tindakan perorangan sedangkan pada realitanya KPU tidak akan bertindak perseorangan melainkan ada kesepakatan dari lembaga yang selanjutnya mengatur ke seluruh jajaran KPU di pusat maupun di KPU daerah.

\section{B. Saran}

Selama masa penelitian, Penulis menemukan beberapa masukan yang perlu disampaikan agar dapat membenahi sistem hukum di Indonesia. Adapun saran yang dapat penulis sampaikan sebagai alternatif pemecahan masalah adalah sebagai berikut:

1. Kekuatan hukum yang diatur di dalam UU Pemilu perlu dipertegas dengan memberikan pengaturan yang jelas tentang putusan Bawaslu apakah benar bersifat final mengikat atau tidak. Apabila, bersifat final dan mengikat maka di dalam Pasal 469 tidak perlu ada kata kecuali yang membuat putusan tersebut tidak mengikat. Pengaturan tentang wewenang Bawaslu dan wewenang PTUN sebaiknya 
dipisahkan, UU Pemilu sebaiknya memberikan ruang kepada para pihak untuk memilih apakah menyelesaikan melalui Bawaslu atau PTUN dan apabila pilih dari salah satu tidak ada lagi upaya hukum lain, dengan kata lain putusan Bawaslu atau PTUN sama sama final dan mengikat.

2. Sanksi yang diatur sebaiknya dipertegas dengan memberikan wewenang kepada kepolisian untuk bertindak tanpa adanya laporan, apabila ditemukan tindakan dari KPU yang melanggar aturan yang ada, maka kepolisian dapat bertindak langsung memeriksa, dan menyidik. Sehingga ada ketakutan dari KPU apabila melakukan tindakan diluar ketentuan yang ada.

3. Pengaturan tentang DKPP sebagai lembaga pengawas kinerja dari lembaya penyelenggara pemilu harus ditambah. DKPP harus berperan aktif dalam melihat dan memberikan sanksi tegas serta langsung kepada penyelenggara pemilu (KPU dan Bawaslu) apabila ditemukan tindakan-tindakan yang melanggar peraturan. Partai politik atau calon anggota legislatif dari Partai politik juga diberikan kewenangan untuk melaporkan KPU atau Bawaslu apabila terdapat tindakan dari lembaga tersebut yang bertentangan dengan UU Pemilu.

\section{DAFTAR PUSTAKA}

\section{A. Buku:}

Andayani, Dwi dan Clarisa Chevly Diory. Politik Hukum Pelaksanaan Pemilihan Umum Serentak. Jakarta: Rafikatama, 2017.

Arifin, Zaenal. Metode Penulisan Ilmiah. Jakarta: Pustaka Mandiri, 2002.

Asikin, H. Zainal dan Amiruddin. Pengantra Metode Penelitian Hukum. Jakarta: Persada, 2006. 
Asshidiqie, Jimly. Menuju Negara Hukum yang Demokratis. Jakarta: Kelompok Gramedia, 2006.

Fajar ND, Mukti dan Yulianto Achmad. Dualisme Penelitian Hukum Normatif dan Empiris. Yogyakarta: Pustaka Belajar, 2015.

Jurdi, Fajlurrahman. Pengantar Hukum Pemilihan Umum. Jakarta: Kencana, 2018.

Marzuki, Peter Mahmud. Penelitian Hukum Edisi Revisi. Jakarta: Kencana Prenada Media Group, 2013.

Riwanto, Agus. Hukum Partai Politik dan Hukum Pemilu di Indonesia. Yogyakarta: Thafa Media, 2016.

Sitepu, P Anotnius. Studi Ilmu Politik. Yogyakarta: Graha Ilmu, 2012.

Surbakti, Ramlan. Penegakan Hukum Pemilu dan Pilkada. Jakarta: Kelompok Gramedia, 2016.

\section{B. Internet}

Indra Komara, "Pernah Jadi Napi Korupsi, M. Taufik Resmi Daftar Caleg", https://news.detik.com/berita/4121677/pernah-jadi-napi-korupsi-m-taufikresmi-daftar-caleg. Diakses tanggal 09 Oktober 2018.

Untung Widyanto, "Bawaslu Loloskan Taufik Gerindra, KPU DKI Tunggu Putusan MA”, $\quad$ https://metro.tempo.co/read/1123284/bawaslu-loloskan-taufikgerindra-kpu-dki-tunggu-putusan-ma. Diakses tanggal 09 Oktober 2018. 